\title{
РЕНОВАЦИЯ ЖИЛЬЯ В РОССИИ. ЕВРОПЕЙСКИЙ ОПЫТ
}

(C) 2020 Реймер Александра Павловна

студент

Сибирский федеральный университет, Россия, Красноярск

(c) 2020 Мухин Дмитрий Сергеевич

студент

Сибирский федеральный университет, Россия, Красноярск

(C) 2020 Аленичева Анастасия Валерьевна

студент

Сибирский федеральный университет, Россия, Красноярск

(C) 2020 Фалилеева Дарья Александровна

студент

Сибирский федеральный университет, Россия, Красноярск

\section{(c) 2020 Шевченко Михаил Олегович}

студент

Сибирский федеральный университет, Россия, Красноярск

В статье поднимается проблема с нехваткой качественного жилья в России. Выполняется сравнение методов реконструкции. Анализируется Западный опыт. Как итог, на основе проведенного исследования, предлагается решение по изменению подхода к реконструкции и новой застройке.

Ключевые слова: строительство, реконструкция, программа реновации, жилищный фонд, опыт.

Одним из наиболее основных вопросов нынешней Российской Федерации считается проблема с квартирами. Уже давно не секрет, что существенная доля жителей государства, в особенности в крупных городах, испытывает потребность в улучшении жилищных условий, а то и в приобретении хоть какого-то собственного квадратного метра. Обеспеченность жильем и его доступность для населения является важным фактором социально-экономического развития страны. Так как приобретение жилья требует существенных вложений, а население у нас небогатое, доходы от 100 тыс. получает примерно $3 \%$ населения, то ситуация с жильем приводит к другим серьезным проблемам:

- кризис института семьи;

- снижение рождаемости;

- комфорт и благополучие граждан.

По своим финансовым возможностям многим приходится жить в коммунальных квартирах, общежитиях и бараках, в захудалых и аварийных домах. Высокие цены на жилье не позволяют многим уже взрослым детям уходить от совместной жизни с родителями. Так как проживать с родителями заранее значительно экономичнее, нежели чем снимать квартиру, или брать его в ипотеку. В случае даже, если есть ресурсы на приобретение жилья, то купленное жилье можно сдавать и поддерживать более высокий уровень жизни, либо не покупать жилье, а тратить деньги на иные цели.

Последний раз пик массовой стройки наблюдался в 1960-е - 1980-е гг., когда весь Советский Союз оказался застроен типовыми «хрущевками» и «брежневками». Последние, в свою очередь, заселялись переселяющимися из бараков и коммунальных квартир семьями самого разного социального уровня и материального достатка. В результате, в СССР была практически искоренена проблема «бездомности» работающего населения. Практически все советские граждане - жители городов, за исключением представителей «социального дна», ведших асоциальный образ жизни, таким образом, стали обладателями квартир или, хотя бы, комнат в общежитиях.

После 80-х масштабных строек больше не наблюдалось. От бывшей застройки нашему поколению достались дома срок службы, которых вот-вот уже будет исчерпан. Жилье, построенное в те года, морально и физически устарело. Да, на первый взгляд может показаться, что в нашей 


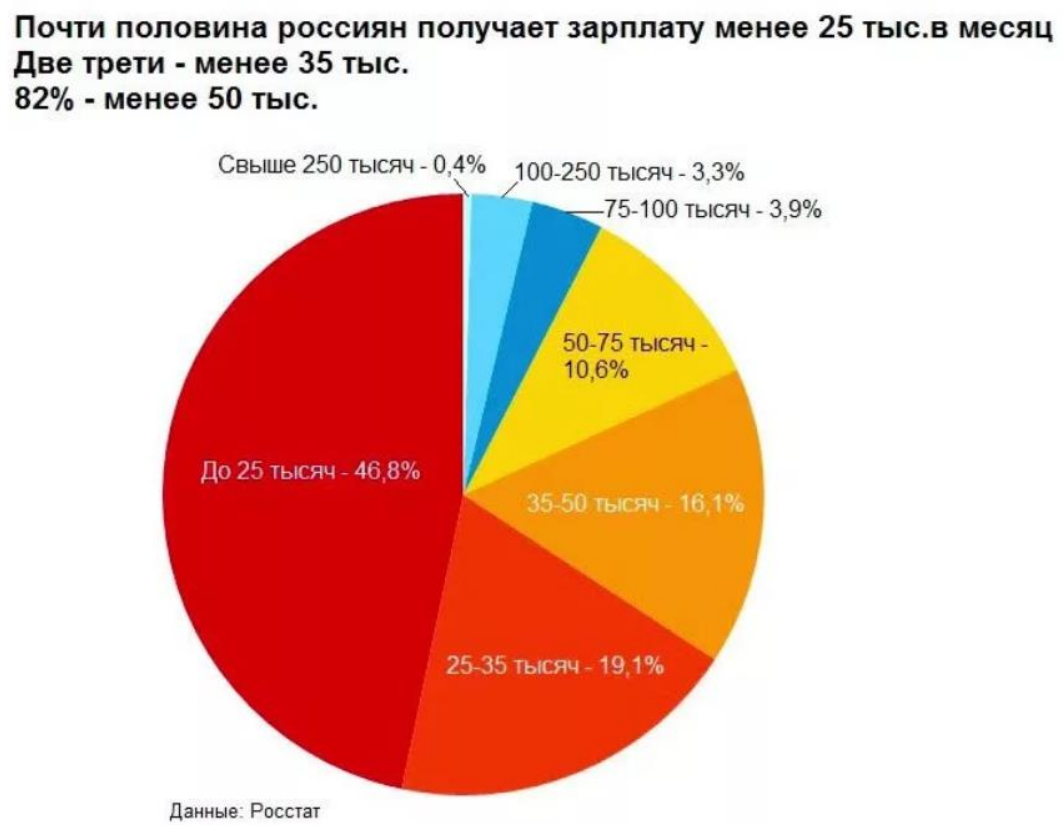

Рисунок 1. Уровень зарплаты по стране

1966 - 1970rr.

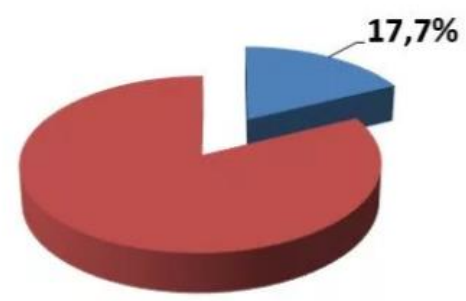

1981-1984 rr.

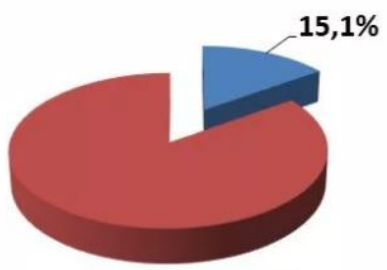

Рисунок 2. Удельный вес капиталовложений в жилищное строительство в СССР (Построено квартир: в 1960 г.-2млн., 1984 г.- млн.)

стране таких домов не так много, но по статистике жилого фонда, в России общая жилая площадь зданий, построенных за рассматриваемый период, составляет около 10\%, что по статистическим показателям считается весьма значительно.

Все вышесказанное и послужило тем, что государству пришлось обратиться к проблеме обеспечения граждан жильём и реконструкции устаревших построек. Разрабатываются различные стратегии и программы, направленные на решение жилищной проблемы. Ряд проектов получил государственное финансирование.

Не так давно в Госдуму был добавлен следующий законопроект о всероссийской программе реновации жилья. Большая часть в законопроекте несомненно взята из нормативной базы по программе реновации в Столице, запуск которой был дан еще в 2017 году, а его завершение должно произойти аж к 2035 году. При этом на месте старых домов возводятся здания большей площади, а увеличение этажности позволяет 
окупить затраты на строительство. Общероссийская реновация, согласно плану законодателей из Санкт-Петербурга, должна принимать во внимание московский опыт, но иметь ряд отличий. Законопроект предполагает проводить реновацию не только отдельного дома, но и квартала, района или микрорайона, а также возводить на освобожденной территории не только жилье, но и другие объекты, изменять целевое назначение земельного участка. На сегодняшний день Москва является единственным проектом, который начал реализовываться. Так как в ходе проекта предусматривается полный снос существующего здания и на его месте строительство нового. То другие же города не могут себе такого позволить по нескольким причинам, это незаинтересованность инвесторов, а другая, которая остро стоит перед всей страной, это отсутствие федерального финансирования, вырезка из законопроекта «реконструкция не потребует расходов из бюджета РФ, финансирование должны найти местные власти». А как мы все знаем, что и местным властям на нас «наплевать», то до восстановления старых домов с сохранением истории нам с вами далеко. Если мы и дождемся обновления, то это будет $100 \%$ снос, со строительством новых домов.

Так как в России все больше зданий с течением времени устаревают, теряя свой вид и первоначальный привлекательный облик. То у архитекторов и инженеров возникает задача в поиске новых решений реконструкции зданий и придания современного облика городу. Выбор ярких цветовых решений при реконструкции уже не являться раздражителем. Цвета гармонизируют с окружающим ландшафтом, создают настроение, и не выглядят при этом раздражающе.

Реконструкция жилищного фонда 60-80 х годов происходит в основном путем достройки этажей, террас, балконов, лоджий, надстройки мансард и повышения этажности, применения объемно-планировочных решений для увеличения полезной площади, изменения архитектурного облика здания, перехода на более экономные инженерные сети и энергоэффективные материалы и т.п.

Тем владельцам квартир, чьи дома уже совсем исхудали, а очередь реконструкции до них еще не дошла, с целую усовершенствовать жилищные условия приходится проводить перепланировку, переустройство, реконструкцию комнат, а в некоторых случаях даже возводить самовольные постройки на придомовой территории, что без разрешения соответствующих органов может привести к судебному разбирательству, а в худшем случае, при неправильных реконструкциях, влияющих на нагрузки дома, к разрушению всей постройки.

В большинстве европейских стран реконструкция жилой территории уже началась. Проекты не предусматривали полного сноса жилых зданий, так как по их экономике было дешевле реконструировать, чем сэкономить. Реконструкция составляла $30 \%$ от стоимости сноса и нового строительства домов, то есть практически в три раза экономнее.

Рассмотрим реконструкцию на примере Германии. «В двадцатые годы прошлого столетия в восточной Германии возникли спальные рабочие районы с так называемыми пятиэтажками, которые составляли процентов 60 всего жилого фонда. Но в промежуток послевоенного развития правительство взялось за массовую реорганизацию, и была применена эволюционная реновация.

В Германии всерьез взялись за проект реконструкции, реконструкцией жилищного фонда послевоенных лет занимались в рамках проекта Regeneration East, которым руководил архитектор Штефан Форстер. Он работал в двух небольших городках, Лайнефельде и Галле, и показал, что устаревшие пятиэтажки можно превратить в современное привлекательное жилье. Реконструкция связана с изменением конструктивной схемы здания. Конструктивные изменения предусматривали частичный снос нескольких блоков и строительства между ними новых. При реконструкции 6-этажного жилого дома архитекторы приняли решение удалить два верхних этажа. Они стремились не только уменьшить здание, но и сделать его более разнообразным, тем самым здания порой получались длинными, бывали даже по несколько километров. Из-за сноса некоторых секций у дома появлялся силуэт. Что положительно влияло на дворовой свет.

С точки зрения авторов проекта уменьшение количества квартир «создает ощущение неприкосновенности частной жизни». Реконструкция фасада и не стандартное цветовое решение придало зданию современный облик. Также одним из обязательных правил было создание отделений придомовых зон. Чтобы можно оставить велосипед или коляску, разбить сад или поста- 
вить столики и шезлонги - у жителей панельного дома появился небольшой участок земли. Достичь этого удалось с помощью кирпичной кладки вдоль первого этажа здания. Получилась своего рода буферная зона между зданием и улицей.

А что в России?

В нашем случае ситуация с реновацией имеет как положительные, так и отрицательные стороны. Суть проекта реновации заключается в сносе ветхого жилья на месте которого возводятся новые здания, кардинально отличающиеся от первоначальных, в связи со значительными затратами на реконструкцию. В отличие от ранее описанной системы реновации в Европе, которая направлена на устранение морального износа за счет потери количества квартир, но с сохранением истории, реновация в России, зачастую, выбирает здания не по его аварийному состоянию, а по ценности и выгоде от географического расположения новой постройки. Само представление программы в Москве, а именно снос всех домов без разбора, которые правительство Москвы желало включить в эту программу, уже выглядит удручающе.

Рассмотрим и проанализируем опыт реконструкции в России. Сравнительно недавно в административном центре Иркутской области образовалось «кладбище убитых домов». В связи с чем это связано? С тем что в последнее время на месте исчезающих старинных усадеб вырастают бетонные постройки современного типа. И это проблема не одного города, а всей страны. по данным общественного движения «Архнад3ор», в 2010-2018 годах в Москве снесли более 160 исторических зданий, среди которых были постройки XVII-XIX в.в. Общественники еще в 2016 году призывали власти Москвы не уничтожать здания старше 1917 года, однако Столичная муниципальная госдума большинством голосов проголосовала против. Под снос шли не только исторические здания, но и памятники архитектуры. В 1990-х особняки в центре просто сжигали, чтобы не заморачиваться с реставрацией и поставить на их месте железобетонных болванчиков. В нулевых под видом реконструкции были уничтожены Военторг на Воздвиженке, историческая застройка Остоженки и Цветного, переделан после пожара Манеж. Сейчас реставрируются здания в центре Москвы, но продолжают ветшать и разрушаться подмосковные усадьбы»,- отмечает Луценко.
По всему вышесказанному понятно, что от сноса зданий страдают все, в первую очередь сами хозяева квартир, чьи дома попадают под снос, теряют свои родные квартиры, взамен получают порой худшие варианты, в других районах, без ремонта, с меньшей площадью. Да, в конце строительства им обещают, что вернут их на прежнее место, в новые дома, но к сожалению, это все только слова. Вот высказывания властей Москвы «в центре жилья нет, мы вас переселим временно в другое место, а потом, через несколько лет, когда выстроим жилье в центре города, сразу же вернем назад». Естественно люди не понимали, как так можно - временно куда-то переселить, а потом вернуть назад. Очевидно, что они не вернутся через несколько лет на свое место. Все это больше напоминает принудительное переселение.

Почитав мнения людей, касаемо данной ситуации, проштудировав разные источники, как отечественных, так и европейских сайтов, мы нашли идеальный вариант реконструкции. Вариант был замечен в Бордо, сама идея заключалась в достижение экологичного жилья, как можно более экономичным и устойчивым способом. Бюджету было уделено большое внимание. Стоимость квадратного метра достройки составляла 365 евро (в среднем 50 тысяч евро за квартиру), при этом арендная плата для жильцов не повысилась.

Самый главный плюс данной реконструкции в том, что разработчики учли опыт других стран с переселением людей на время реконструкции, и теперь во время реализации их проекта каждая из 530 квартир была заселена, все семьи оставались в своих жилищах во время строительных работ.

Разработчики никак не вмешивались в главную часть структуру здания, не переделывали лестницы и этажи, было модернизировано лишь домовое техническое оснащение. Началось все как полагается, конечно, с реконструкции внутренних помещений, чтобы придать им новые качества: увеличить свободное место, добавить уличного света и обзора, модернизировать. К существующим зданиям были пристроены зимние сады, работающие как пассивные солнечные коллекторы, балконы глубиной до 4-х метров. Окна небольших размеров были заменены на широкие застеклённые раздвижные двери, которые открывают проход в приятное частное полуоткрытое пространство. Достройка зимних 
садов послужила улучшением энергетических характеристик конструкций здания. С другой стороны, лёгкий фасад из прозрачных гофрированных поликарбонатных панелей и стекла в алюминиевых рамах оснащён светоотражающими солнечными шторами.

Благодаря планированию и составлению графика работ на модернизацию одной квартиры уходило не более 15 дней, в зависимости от ремонта. при возведении использовались сборные модули, которые быстро монтируются, как строительные леса перед зданием. Предварительно соединённые плиты и колонны транспортировались на стройплощадку и поднимались на место с помощью крана. Бетоном заливали только фундамент. Во время реконструкции квартир полдня уходило на укладку бетонной плиты, 2 дня на адаптацию старого фасада, 2 дня на установку нового фасада и 8-10 дней на ремонт интерьеров.

Проект в Бордо показал, что при грамотном подходе и желание государства можно сохранить все памятники архитектуры, оставить всех владельцев на своих местах, и при этом все пройдет быстро и качественно, все будут довольны. А пока целью реновации будет только получение прибыли частными компаниями, а не решение проблемы ветхого жилья, то в нашей стране ничего не изменится.

Закону пора начать наводить порядок в своей стране.

\section{Библиографический список}

1. Алексеенко Ю.С., Грин И.Ю. Европейский опыт реконструкции типовых микрорайонов [Электронный реcypc]. URL: http://pnu.edu.ru/nionc/pub/articles/1285/ [дата обращения: 25.10.2020].

2. Байрамуков С. Х., Эбзеев М.Б. Методологический подход к формированию системы энергетических обследований в жилых зданиях серий [Электронный ресурс]. URL: http:// http://www.ivdon.ru/magazine/archive/ n4y2011/582 [дата обращения: 27.10.2020].

3. Байрамуков С. Х., Долаева 3.Н. Комплексный подход к проблеме модернизации жилищного фонда [Электронный ресурс] URL: http://www.ivdon.ru/magazine/archive/n4y2013/2048 [дата обращения: 25.10.2020].

4. Интернет-журнал о дизайне и архитектуре [Электронный ресурс]. URL: http://www.berlogos.ru/article/ snosit-nelzya-rekonstruirovat/ [дата обращения 25.10.2020].

5. Валиев С. Ф., Ишемгулов М.Н. Факторы, влияющие на себестоимость жилищного строительства [Электронный ресурс]. URL: https://moluch.ru/archive/136/38256/ [дата обращения 28.10.2020]. 